виражати свої думки; високий рівень розвитку технічних, математичних здібностей; розвита уява [4].

Забезпечивши належний підбір засобів та методики викладання за допомогою IКТ, можна якісно впливати на показники професійної компетентності студентів технічних закладів освіти, а саме: знання, вміння та навички. Вивченню цього питання приділило увагу багато науковців, які в певних галузях досягли кардинально нових рівнів, дійшли висновку, що професійна підготовка фахівців неможлива без сучасних педагогічних та інформаційних технологій [3, с. 13].

Професійне самовдосконалення системи освіти є одним із головних чинників, які мотивують удосконалюватися майбутнім фахівцям, прагнення до саморозвитку, самоосвіти. Під час здійснення професійного самовдосконалення знань суттєво інтенсифікують навчальний процес засоби IКТ, тому завдання всіх закладів освіти якомога швидше забезпечити оснащення необхідним обладнанням навчальних аудиторій та реалізувати навчальний процес на новому рівні, про що йдеться в Законах про освітню діяльність держави, які є підставою для дій щодо вдосконалення освітньої системи.

Навчання майбутніх інженерів-програмістів у період технологізації всіх сфер життя суспільства неможливо уявити без використання засобів ІКТ, оскільки вони впливають на формування професійних знань, покращують практичний рівень умінь та $є$ одним із базових інструментів у трудовій діяльності. Перспективою подальшого дослідження $є$ створення електронного курсу з фахової дисципліни для студентів інженерів-програмістів.

\title{
Література
}

1. Головань М. Інформатична компетентність: сутність, структура і становлення / М. Головань // Інформатика та інформаційні технології в навчальних закладах. - 2007. - № 4. - С.62 - 69. 2. Закон України «Про професійний розвиток працівників» від 12 січня 2012 року, № 4312-VI. 3. Клочко В. І. Формування знань майбутніх інженерів з інформаційних технологій розв'язування диференціальних рівнянь : монографія / В. І. Клочко, 3. В. Бондаренко. - Вінниця : ВНТУ, 2010. 216 с. 4. Романова С. С. популярных профессий. Психологический анализ и профессиограммы/ Є. С. Романова. - СПб.: Питер, 2008. - 462 с. 5. Хуторской А.В. Современная дидактика/ А. В.Хуторовський. - СПб. : Питер, 2001. - 544 с. освіти дорослих НАПН України

\section{РОЗВИТОК ЛЮДСЬКИХ РЕСУРСІВ НА ПІДПРИЕМСТВІ ЯК ЧИННИК РОЗВИТКУ ОСОБИСТОСТІ}

Пазюра Н. В. Розвиток людських ресурсів на підприємстві як чинник розвитку особистості.

У статті здійснено аналіз різних підходів науковців до визначення поняття корпоративного розвитку людських ресурсів, уточнено сутність та мету корпоративного. Автор визначає особливості його функціонування та вплив теорії на практику корпоративного розвитку як необхідної умови розвитку особистості.

Ключові слова: розвиток людських ресурсів, розвиток особистості, корпоративна підготовка.

Пазюра Н. В. Развитие человеческих ресурсов на предприятии как фактор развития личности.

В статье рассматриваются различные подходы ученых к определению понятия корпоративного развития человеческих ресурсов, уточнены сущность и цель корпоративного развития. Автор выявляет особенности его функционирования, а так же влияние теории на практическую деятельность, как необходимого условия развития личности.

Ключевые слова: развитие человеческих ресурсов, развитие личности, корпоративная подготовка.

Pazyura N. V. Corporate human resource development as a factor of personal improvement. 
In the article different approaches to the definition of human resource development are considered. The nature and aim of corporate human resource development are clarified on this basis. The author has found peculiarities in its functioning and specified the influence the theoretic views on the practice of human development that is considered as essential part of personal improvement.

Key words: human resource development, personal development, corporate training.

Успішна діяльність компанії будь-якого напряму в сучасних умовах цілковито залежіть від рівня професійної підготовки персоналу, що працюють в організації. У всьому світі людський капітал компанії визнається як наріжний камінь їі конкурентоспроможності на внутрішньому та зовнішньому ринках, а внутрішньофірмова підготовка вважається основною формою розвитку людських ресурсів, виховання диверсифікованих навичок та загального культурного рівня працівників. Необхідність розроблення концепції внутрішньофірмової підготовки - важливого складники розвитку людських ресурсів, виявлення інноваційних та ефективних стратегій корпоративного навчання в зарубіжному досвіді зумовили здійснення грунтовного аналізу концептуальних ідей розвитку людських ресурсів на підприємстві, різних підходів до визначення та розуміння цього складного та багатоаспектного явища.

Mema cmammi - проаналізувати погляди науковців світу та на основі їх визначень уточнити сутність та мету корпоративного розвитку людських ресурсів, вивчити теоретичні засади концепції, виявити особливості функціонування та впливу теорії на практику розвитку людських ресурсів на підприємстві як необхідної умови розвитку особистості.

Розвиток людських ресурсів в умовах підприємства привертав увагу багатьох науковців світу. Серед вітчизняних дослідників можна виокремити праці Н. Артеменко, І. Бондаренка, А. Гошка, Г. Дмитренка, А. Козаченко, В. Колпакова, В. Красношапки, які розглядають питання управління людськими ресурсами як на загальнодержавному рівні, так і на рівні організації. Соціально-економічні аспекти розвитку підприємств та їх соціальної політики вивчалися В. Вовком, О. Кириленко, О. Козиревою, В. Решетовим, проблема формування людського капіталу та його менеджменту в системі професійної підготовки як чинника конкурентоспроможності підприємства були об’єктом досліджень О. Грішнової, І. Кочуми, 3. Магамедінової, Т. Синиці, питання організаційно-економічних механізмів реалізації інноваційних методів професійного навчання економічно активного населення порушувалися I. Заюковим, регулювання якості робочої сили В. Кравченко, Н. Шульгою.

У контексті нашого наукового пошуку значний інтерес становлять результати досліджень науковців Східної Азії, а саме Японії та Південної Кореї з проблеми розвитку людського ресурсів (Джі Лін, Сун Ім, Сокон Кім, Шігеру Накаяма, Танака Казутоші). Серед провідних науковців, які присвятили свої розвідки цьому питанню, також необхідно назвати А. Джілл, Х. Кок, П-Е. Еллстром, К. Рубенсона, Д. Вілмса, С. Ларсон, К. Іллеріс та інших. Однак, багато аспектів цього складного явища все ще залишається поза увагою, що і зумовило наш вибір теми дослідження.

Сучасний виробничий персонал повинен бути добре освіченим та підготовленим для виконання складних завдань виробництва та підтримки конкурентоспроможності компанії на ринку, тому його розвиток та неперервна професійна підготовка перетворюються на корпоративну необхідність (Р. Якобс, М. Джоунс, Р. Дурр, Р. Мурдік). Уважається, що професійна підготовка працівників є важливим завданням розвитку людських ресурсів, доведено, що компанії, які усвідомили цей постулат, $є$ більш продуктивними та ефективними. Такий погляд на навчання концентрує увагу на позитивних змінах, які відбуваються в компанії завдяки навчанню, та розглядає розвиток людських ресурсів як «галузь теоретичних досліджень та практичних дій для виховання довгострокового, професійного потенціалу на індивідуальному, груповому та організаційному рівні компанії» (К. Воткінс).

Проведене дослідження показало, що феномен розвитку людських ресурсів не має єдиного визначення мети. На розуміння цього процесу впливає контекст, у якому 
реалізується. Згідно з думкою Дж. Маклін, галузь розвитку людських ресурсів викликає багато обговорень щодо визначення поняття та з'ясуваня його сутності. Дискусійним $€$ питання теоретичних засад, особливостей функціонування, впливу теорії на практику розвитку людських ресурсів, необхідності врахування глобалізаціїних тенденцій [3, c. 380-382]. Науковці, які опікуються дослідженнями корпоративних змін шляхом навчання персоналу, розглядають розвиток людських ресурсів як «галузь досліджень та практичної діяльності, що відповідає за підтримку довгострокових, професійноорієнтованих компетенцій на індивідуальному, груповому та організаційному рівнях» (К. Воткінс) [2, с. 615-616].

Процес визначення розвитку людських ресурсів є складним ще й тому, що, на думку Т. Гараван та Т. Нетчера, розвиток людських ресурсів не оформився як чітка концепція та теоретична галузь. Це порівняно нова галузь у практичній діяльності та теоретичних дослідженнях навіть у США, хоча Д. Сімон зауважує, що «це новий термін, а концепція стара». У. Руона зазначає, що дослідники в США мають різні позиції щодо розвитку людських ресурсів, те саме підкреслюють і науковці інших країн (Дж. Джіллі, С. Егленд, Дж. Маклін) [7, с. 65]. К. Воткінс назвав розвиток людських ресурсів окремою галуззю досліджень (1990).

На початку нового тисячоліття спостерігаємо появу нових теорій (постпозитивізму У. Трочінм (1999) та критичного реалізму - А. Сейер (2000)), які вплинули на розвиток людських ресурсів. Р. Свансон та С. Лінхем уважають, що «дебати навколо парадигми дослідження поглиблюють розуміння теоретичних засад та забезпечують основу для нових досліджень». Окрім того, на дослідження розвитку людських ресурсів все більше впливає постмодернізм, який є основою галузі організаційних досліджень (М. Алвессон, С. Дітс), і концепція стратегічних змін (Дж. Форд, Л. Форд) [5, с. 348-352].

У США Надлер у 1983 р. уперше визначив розвиток людських ресурсів як «організовану навчальну діяльність персоналу компанії в певний період часу задля досягнення змін у виконанні ним професійних обов'язків або загального розвитку особистості в компанії чи організації» [7, с. 64]. Згідно з позицією Р. Свансона, розвиток людських ресурсів - це процес формування та удосконалення компетентності шляхом організаційного розвитку, підготовки персоналу задля поліпшення результатів професійної діяльності. К. Воткінс, В. Марсік у 1997 р. висловили ідею, що працівники сфери розвитку людських ресурсів повинні виробити концепцію. К. Воткінс уважає, що розвиток людських ресурсів - це галузь в науці та практиці, спрямована на довгостроковий професійний розвиток на індивідуальному, груповому та організаційному рівнях. П. Маклаган у 1989 р. присвятив роботи вивченню діяльності організаторів розвитку людських ресурсів (адміністратор, оцінщик, менеджер, розробник навчальних матеріалів, радник з питань розвитку персональної кар'єри, інструктор, аналітик ринку та потреб, агент організаційних змін, дизайнер програм).

3-поміж досліджень питання розвитку людських ресурсів в азійських країнах гідним уваги є роботи тайванських учених М. Куо, Н. Маклін (1999), які вважають, що успіх Тайваню підтверджує ідею щодо позитивного впливу розвитку людських ресурсів шляхом професійного навчання на економічне зростання країни [7, с. 65]. С. Гурлей з'ясовує сутність розвитку людських ресурсів і визначає ії як галузь, яка «сфокусована на теорії і практиці підготовки, розвитку та навчання в межах організації як для індивідууму, так і в контексті корпоративної стратегії та формування організаційної компетенції» [5, с. 348$352]$.

У 2000 р. Дж.Н. Маклін здійснив порівняльний аналіз визначень розвитку людських ресурсів науковцями різних країн та дійшов висновку про існування великої кількості варіантів тлумачення цього поняття, які відрізняються залежно від історичного, економічного, культурного, політичного контексту. Якщо визначення розвитку людських ресурсів не відрізняється у Франції (Б. Хіллон, Дж.Н. Маклін) та Китаї (Б. Ян), то в Таїланді більша увага приділяється розвитку громади (С. На Чянгмай). Дж. Маклін у 2000 
р. запропонував універсальне визначення, яке, на його думку, може використовуватисяь незалежно від культурних особливостей країни. Згідно з позицією науковця, розвиток людських ресурсів - це процес або діяльність, яка 3 самого початку або протягом тривалого часу має потенціал розвивати професійні знання дорослої людини, поширювати iї досвід, підвищувати продуктивність та одержувати задоволення від власної професійної діяльності, незалежно від того, хто одержує вигоду - індивідуум, група, громада, нація або людство загалом [6, с. 271-273]. Отже, розвиток людських ресурсів має безпосереднє відношення до «підвищення навчального потенціалу індивідуумів, колективів і організації через розвиток i запровадження навчальних заходів задля оптимізації процесу індивідуального та корпоративного розвитку, підвищення ефективності підприємства» (Н. Чалофскі, 1992) [2, с. 615-616].

Проведене дослідження показало, що, окрім багатьох філософських дискусій щодо природи розвитку людських ресурсів, не менше обговорень проводиться щодо його мети. Увагу зосереджено на з'ясуванні питання, яке з двох понять - навчання або діяльність $\epsilon$ важливішим (Е. Холтон). Т. Хетчер уважає, що дослідження розвитку людських ресурсів повинні концентруватись навколо економічної вигоди, теорії систем, соціальної вигоди та етики розвитку людських ресурсів. Отже, основна мета розвитку людських ресурсів може бути сформульована як забезпечення навчання людських ресурсів задля кращого виконання ними професійних обов'язків [5].

Головна мета розвитку людських ресурсів - це покращення діяльності системи, формування потенціалу для майбутнього ефективного функціонування задля досягнення високих показників професійної діяльності. Навчальна діяльність не може бути відділена від інших видів діяльності в системі та має бути поєднана 3 іншими заходами 3 удосконалення функціонування системи. Розвиток людських ресурсів повинен співпрацювати 3 функціональними департаментами задля досягнення кінцевої мети. Використання знань, одержаних у період навчання у професійній діяльності, $\epsilon$ найважливішим завданням. Як усі компоненти будь-якої системи (у нашому випадку організації), розвиток людських ресурсів повинен забезпечувати ефективність компанії. Основне завдання - визначення, як професійна діяльність має бути інкорпорована в теорію і практику розвитку людських ресурсів. Згідно з таким функціональним підходом розвиток людських ресурсів має стратегічну цінність для організації, якщо вона поєднує унікальну цінність досвіду працівника із стратегічними завданнями організації (Р. Торрако, Р. Свансон) [1, с. 205-207].

Отже, можна зробити висновок, що не існує консенсусу щодо концептуальної сутності розвитку людських ресурсів та його мети. Визначення варіюються залежно від філософських поглядів дослідників, але безперечним $\epsilon$ те, що розвиток передбачає неперервність та послідовне виконання стратегій, спрямованих на підвищення ефективності професійної діяльності на всіх рівнях компанії.

Здійснений аналіз матеріалів показує, що практична діяльність у галузі розвитку людських ресурсів починалася з навчання та розроблення дизайну програм підготовки, а 3 часом набула функцій навчання та всебічного розвитку працівника (Р. Якобс). Традиційно галузь розвитку людських ресурсів визначалася як напрям практичної діяльності (С.А. Ліхнам 2000), але 3 часом почала функціонувати на основі теорії і практики (Р. Якобс 2000). Необхідність теоретичних досліджень була сформульована Т. Хетчером, який у 2000 р. висловив думку, що «без концентрації на теоретичній основі та практиці розвиток людських ресурсів залишиться нетеоретичним за сутністю, що буде підривати довіру» [5, с. 348-352].

Останніми роками спостерігається пожвавлення дебатів щодо теоретичної основи розвитку людських ресурсів. П. Маклаган, Д. Градоус, Р. Свансон (1995 р.) уважають основою для розвитку людських ресурсів теорію систем (яка пояснює взаємозв'язки в межах організації, до яких звертається розвиток людських ресурсів), психологію (що надає розуміння, як здійснюються інтервенції і який вплив вони мають) та економічну 
теорію (яка пояснює, чому приймаються інвестиційні рішення у розвиток людських ресурсів). Причому Д. Градоус, П. Маклаган, У. Руона, Р. Свансон більшою мірою спираються на теорію систем, та менше на психологічну або економічну основу, яким надають перевагу Е. Холтон та Р. Торрако. Дж. Маклін наполягає на необхідності врахування інших теорій, які теоретично обгрунтовані пізніше, наприклад, теорія діяльності Л. Вейнберга або етики. Т. Хетчер зазначає, що «психологія, загальна теорія систем та етика мали найбільший вплив на теорію та практику людських ресурсів». На думку Дж. Філліпс, Р. Свансон, Д. Градоус, економіка асоціюється з вигодою, одержаною від навчання, i фінансові та інші моделі розроблено для пояснення повернення інвестицій від інтервенцій з розвитку людських ресурсів.

Окрім того, проаналізовані матеріали показують, що останнім часом межі досліджень розвитку людських ресурсів поширюються, увага концентрується навколо галузей, які традиційно не вважались такими, що належать до цієї галузі, як-то: організаційне лідерство, корпоративні цінності, питання розвитку виробничого персоналу на рівні суспільства та економіки праці (Л. Донован, В. Марсік (2000)).

Отже, багатодисциплінарність питання та поширення меж досліджень - це основні тенденції цього феномену. Крім того, характерним є відсутність консенсусу щодо концептуально-теоретичної сутності розвитку людських ресурсів, яка залежить від філософських поглядів та знаходиться під впливом низки методологічних засад. Однак, беззаперечним $є$ той факт, що дві фундаментальні теоретичні основи розвитку людських ресурсів - це теорія освіти дорослих та концепція організації, що навчається або корпоративного навчання [5, с. 348-352].

П. Сендж у 1990 р. дав визначення компанії, що навчається як організації, яка постійно поширює свій потенціал для створення майбутнього, та змінюється відповідно до нових реалій бізнес-оточення. Навчання - це активатор здібності змінюватися відповідно до потреб виробництва, і розвиток людських ресурсів відповідальний за «сприяння та моніторинг усіх типів навчання на робочому місці, зараховуючи формальне, неформальне, та випадкове (інформальне) навчання» (К. Воткінс, В. Марсік 1992) [1, с. 205-207]. Ряд авторів (Д. Удріч, М. Гліноу, Т. Джік (1993), В. Марсік, К. Воткінс (1997)) описали організацію, що навчається, як таку, що створює, розподіляє, та використовує знання для зміни засобів, як організацію, що реагує на виклики і завдання виробництва. Вони виокремили сім критеріїв. або діяльнісних імперативів, необхідних для перетворення на організацію, що навчається. Це: створення можливості для неперервного навчання; поширення діалогів та обговорень для розв'язання питань; забезпечення співпраці та навчання в команді; надання можливості для формування колективної точки зору; запровадження системи для створення та розподілу знань; зв'язок компанії з іії оточенням; запровадження стратегічного лідерства для навчання [4, с. 189-191].

Організації, що навчаються, - є такими, що інтегрували до своєї корпоративної культури гарантовану можливість неперервно навчатися, адаптуватися та змінюватися відповідно до вимог оточення. Тому в таких компаніях погляди та уявлення, стратегії, методи та форми навчання зорієнтовано на забезпечення і оптимізацію професійної підготовки всіх працівників. Результати навчання виявляються в постійному покращенні професійної діяльності, якості продукції та послуг, формуванні навичок роботи в команді та ефективності методів менеджменту. Організації, що навчаються, розглядають навчання холістично та намагаються розвивати індивідуумів як компетентних, добре інформованих, критично мислячих особистостей, які намагаються постійно інтелектуально розвиватися $\mathrm{i}$ бути високо кваліфікованими працівниками. Холістичне, трансформаційне навчання спрямовується на персональне зростання (інтелектуальне, психологічне, духовне та моральне), що позитивно впливає на підвищення показників у роботі, персональне задоволення від діяльності та організаційну ефективність [1, с. 205-207].

Отже, здійснений аналіз різних поглядів на питання розвитку людських ресурсів дозволяє зробити висновок про багатоаспектність окресленого поняття та його 
складників. Визначення поняття «розвиток людських ресурсів» відрізняються в різних країнах у трьох вимірах: межі діяльності, цільової групи розвитку та одержувачів результатів розвитку. Розвиток людських ресурсів - це будь-який процес або діяльність, яка має коротко або довгостроковий потенціал розвивати професійні знання дорослої людини, досвід, задоволення як для індивідуальної, так і для групової вигоди, або вигоди організації, громади, нації, людства. Це процес розвитку та вивільнення людських знань завдяки корпоративному розвитку та підготовці персоналу задля покращення діяльності на організаційному, індивідуальному та груповому рівнях. 3 економічного погляду, розвиток людських ресурсів визначається як процес формування людського капіталу шляхом внутрішньофірмової професійної підготовки та розвитку працівників задля поліпшення діяльності компанії. Розвиток людських ресурсів часто представляється як відмінний від навчання та розвитку, увага фокусується на навчанні та розвитку індивідууму та організації.

Подальші наукові пошуки доцільно спрямувати на вивчення нової парадигми корпоративної підготовки, яка допоможе організаціям досягати успіху у мінливому бізнес-оточенні. Висловлюємо думку, що ця парадигма може сформуватись на основі джерел, які ніколи не розглядалися у цьому аспекті раніше: східне філософське осмислення навчання, автономне та неформальне навчання тощо.

\section{Література}

1. Bates R. A. Redefining human resource development: an integration of the learning, performance, and spirituality of work perspectives / R. A. Bates, T. Hatcher, E. F. Holton, N. Chalofsky / (Ed. Aliaga O. A.) Academy of human resource development (AHRD) conference proceedings (Tulsa, Oklahoma, February 28 - March 4, 2001). V.1 - 2. Baton Rouge, LA, 2001. - P. 204 - 213. 2. Chalofsky N. E. Increasing capacity to learn in the learning organization. / N. E. Chalofsky / (Ed. Aliaga O. A.) Academy of human resource development (AHRD) conference proceedings (Tulsa, Oklahoma, February 28 - March 4, 2001). V.1 - 2. Baton Rouge, LA, 2001. - P. 615 - 617. 3. Egan T. M. Organization development: an examination of definitions and dependent variables. / T. M. Egan. (Ed. Aliaga O. A.) Academy of human resource development (AHRD) conference proceedings (Tulsa, Oklahoma, February 28 - March 4, 2001). V.1 - 2. Baton Rouge, LA, 2001. - P. 380 - 387. 4. Hernandez M. The impact of the dimensions of the learning organization on the transfer of tacit knowledge process and performance improvement. / M. Hernandez (Ed. Aliaga O. A.) Academy of human resource development (AHRD) conference proceedings (Tulsa, Oklahoma, February 28 - March 4, 2001). V.1 - 2. Baton Rouge, LA, 2001. - P.189 - 196. 5. McGoldrick J. Theorising human resource development / J. McGoldrick, J. Stewart, S. Watson (Ed. Aliaga O. A.) Academy of human resource development (AHRD) conference proceedings (Tulsa, Oklahoma, February 28 - March 4, 2001). V.1 - 2. Baton Rouge, LA, 2001. - P. 348 - 355. 6. G. N. McLean. Indigenizing knowledge transfer. / G. N. McLean (Ed. Aliaga O. A.) Academy of human resource development (AHRD) conference proceedings (Tulsa, Oklahoma, February 28 - March 4, 2001). V.1 - 2. Baton Rouge, LA, 2001. - P. 271 - 276. 7. Ya-Hui Lien, G. N. McLean. What is it like to be a Taiwanese HR practitioner performing HRD tasks? / Ya-Hui Lien, G.N. McLean. (Ed. Aliaga O. A.) Academy of human resource development (AHRD) conference proceedings (Tulsa, Oklahoma, February 28 - March 4, 2001). V.1 - 2. Baton Rouge, LA, 2001. - P. 64-70.

УДК 372.018.1:376

І. Л. Паласевич, кандидат пед. наук, дочент, Дрогобицький державний педагогічний університет імені Івана Франка

\section{ВЗАЕМОДІЯ ДНЗ ІЗ СІМ'ЄЮ, ЩО ВИХОВУє ДИТИНУ 3 ОСОБЛИВИМИ ПОТРЕБАМИ}

Паласевич Л. І. Взаємодія ДНЗ із сім’єю, що виховує дитину з особливими потребами.

У статті висвітлено основні аспекти виховання дітей з особливими потребами в умовах сім’і; акцентується увага на тому, що подолання труднощів опіки, догляду та виховання залежить від уміння батьків прийняти особливості розвитку дитини, організувати власну поведінку відповідно до 